\title{
INFLUENCE OF OXYGENATION TIME ON CRACK GROWTH IN TITANIUM ALLOY UNDER CYCLIC BENDING
}

\author{
D. ROZUMEK, M. HEPNER
}

\author{
Opole University of Technology, Poland
}

\begin{abstract}
The paper contains the results of tests on the fatigue crack growth in Ti-6 Al- $4 \mathrm{~V}$ titanium alloy. Plane specimens of $4 \mathrm{~mm}$ in thickness with a unilateral notch were used. An analysis of crack growth was carried out for specimens without and after 2 and $4 \mathrm{~h}$ oxygenation process as well as fatigue crack growth rate was determined. From the test results it appears that the fatigue crack growth in the specimens without thermo-chemical treatment differs from the fatigue crack growth in the specimens after oxygenation. It has been also found that the applied surface treatment increases fatigue life of the considered alloy.
\end{abstract}

Keywords: titanium alloy, oxygenation, fatigue crack growth, bending, notch.

Titanium and its alloys are the materials having very good mechanical, physical and chemical properties. Titanium alloys are mainly used in aerospace, armaments, shipbuilding and medical industries, or other fields where the structure weight, high strength and high corrosion resistance are very important. They are applied in production of heat exchangers, water desalting lines and many other products. However, application of titanium is limited, because its wear resistance is low, and its susceptibility to seizing under friction is high. Thus, development and modification of titanium-based materials $[1,2]$ should include not only a proper selection of the alloying elements, but changes of the surface layer properties by suitable surface treatment, as well. Oxygenation of titanium is one of such methods. It uses susceptibility of oxygen to formation of the solid solution in Ti $\alpha$ under high temperature. The authors of this paper discussed that problem [3]. The regularities of titanium alloys surface hardening under saturation in oxygen-containing media were described in $[4,5]$. It is also important, how the applied modification of the surface layer influences fatigue strength and crack growth in the material. Tests of the fatigue crack growth in two-phase titanium alloys are described [6]. Influence of microstructure on the fatigue crack growth was analyzed for turbine blades made of Ti-6Al-4V titanium alloy. It was found that the grain size strongly influenced the crack growth.

The aim of this paper is to determine the influence of the oxygenation time on changes in the material and the fatigue crack growth in Ti-6Al-4V titanium alloy.

Material and testing procedures. The crack growth was considered in Ti-6Al-4V alloy [3, 7] (brand name IMI318, $\sigma_{y}=930 \mathrm{MPa}, \sigma_{u}=977 \mathrm{MPa}$, micro-hardness is $\left.373 \mathrm{HV}_{0.1}\right)$ in the structural aspect of the material. This alloy is a typical two-phase $\alpha+\beta$ structure. Aluminium is dissolving in $\alpha$-phase and stabilizing it, and vanadium stabilizes $\beta$-phase. Plane specimens were made of the as softened bar (hot rolled and after stabilizing annealing), $16 \mathrm{~mm}$ in diameter with a width of $16 \mathrm{~mm}$, thickness of $4 \mathrm{~mm}$ and the unilateral side notches of the root rounding $0.2 \mathrm{~mm}$ and $2 \mathrm{~mm}$ in depth.

The specimens with notches were subjected to oxygenation at a temperature of $900^{\circ} \mathrm{C}$ by 2 and $4 \mathrm{~h}$ in the electric furnace in hot air then the specimens were cooled in the air. Under high-temperature oxidation of titanium and its alloys, the scale including mainly $\mathrm{TiO}_{2}$ and $\mathrm{Al}_{2} \mathrm{O}_{3}$ is formed on the surface, and a part of oxygen diffuses through

Corresponding author: D. ROZUMEK, e-mail: d.rozumek@po.opole.pl 
a layer of oxides and dissolves in the metallic base, causing significant increase of hardness dependent on an amount of dissolved oxygen. Titanium and its alloy are able to form oxygen solid solutions (at temperatures above $500^{\circ} \mathrm{C}$ ) in phases Ti $\alpha$ and Ti $\beta$, and this is a very important feature. In the case of other metals and alloys, oxidation usually causes formation only oxides without oxygenation of the metallic base. Titanium $\alpha$ of the hexagonal compact structure is able to dissolve no more than $34 \%$ at. (14\% by weight) of oxygen, and $\beta$-phase - less oxygen, no more than $3.8 \%$ by weight. After $2 \mathrm{~h}$ of oxygenation at $900^{\circ} \mathrm{C}$, micro-hardness equal to about $800 \mathrm{HV}_{0.1}$ was obtained on the specimen surface (the surface was measured after removal of the layer of oxides). After $4 \mathrm{~h}$ of oxygenation, further increase of micro-hardness to about $890 \mathrm{HV}_{0.1}$ was reported. The material hardening decreased together with the distance from the external surface of the specimen, and it was found for $2 \mathrm{~h}$ at the depth $100 \mu \mathrm{m}$, and for $4 \mathrm{~h}$ at the depth $165 \mu \mathrm{m}$, although the alloy structure changes were seen at the greater depth (Fig. 1). The dissolved oxygen stabilizes $\alpha$-phase, so the top layer contains less $\beta$-phase.
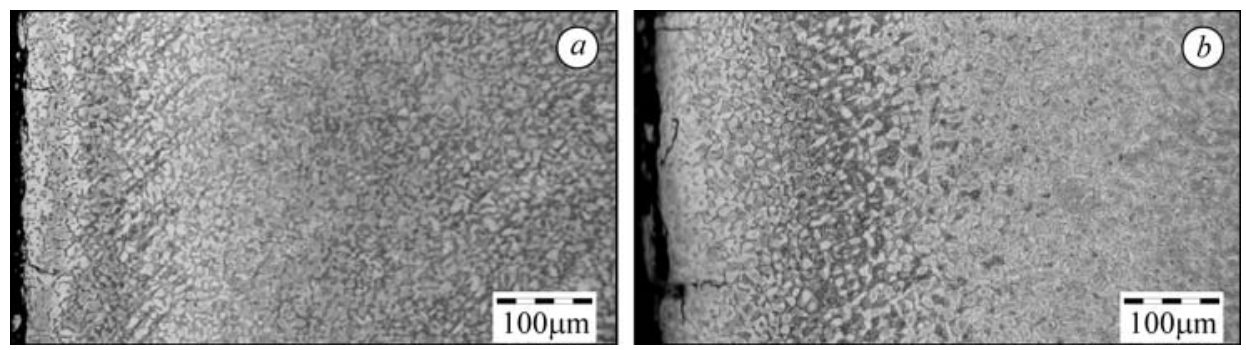

Fig. 1. Cross section of the specimen made of the Ti-6Al-4V alloy after: $a-2$ h oxygenation; $b-4$ h oxygenation.

The tests were performed on the fatigue test stand MZGS - 100 under the loading change frequency of $28.8 \mathrm{~Hz}[6,7]$. The specimens were subjected to cyclic bending with the constant stress ratio $R=\sigma_{\min } / \sigma_{\max }=0$ and amplitude of moment $M_{a}=11.2 \mathrm{Nm}$ $\left(M_{\max }=22.4 \mathrm{Nm}\right)$, which corresponded to the nominal amplitude of normal stress $\sigma_{a}=74.6 \mathrm{MPa}$ before crack initiation. Synchronous sinusoidal variable loadings including the mean value were applied. Crack growth on the specimen surface was observed with the optical method. The fatigue crack increments were measured with the micrometer located in the portable microscope with magnification of 20 times and accuracy up to $0.01 \mathrm{~mm}$. At the same time, a number of loading cycles $N$ was recorded. The results of measurements are shown in the graphs of crack length " $a$ " versus a number of cycles $N$, and the graphs of fatigue crack growth rate $d a / d N$ versus the variability range of the stress intensity factor $\Delta K$.

Results and discussion. Structures without and after oxygenation. Since the plane specimens were cut off along the bar axis, their surfaces contained elongated grains of $\alpha$-phase (with a length of about $50 \mu \mathrm{m}$ ) with precipitations at the boundaries of the disintegrated $\beta$-phase, forming a band structure perpendicular to the applied loading. Fig. 2 shows the specimen surface without thermo-chemical treatment, tested with a number of failure cycles $N_{f}=9.000$. The main crack grows on the planes of the greatest normal stresses. At the fractures, transcrystalline cracks through the grains of $\alpha$-phase predominated, but cracks along the grain boundaries were also observed, especially in the clusters of $\beta$-phase. In the tested material, there were also secondary short cracks, developing from the main crack. In the alloy without oxygenation, short cracks were located at different directions with respect to the specimen axis. These secondary cracks running from the main (long) are often generated at the phase boundary $\alpha$ and $\beta$, forming slips which run along $\beta$-phase precipitations. Also the cracks which stop in 


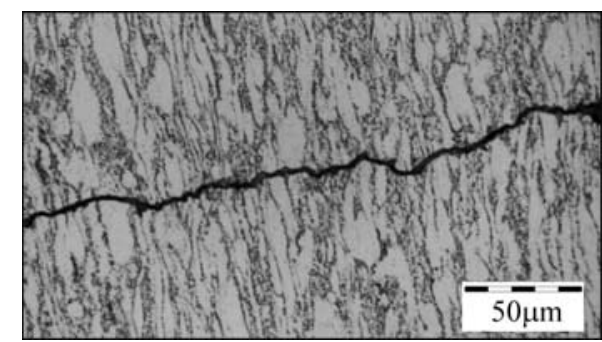

Fig. 2. Fatigue crack growth in the Ti-6Al-4V alloy without thermo-chemical treatment. $\alpha$-phase and do not reach the phase boundary can be observed. The cracks developing in the grains of $\alpha$-phase are often stop at the phase boundary $\alpha$ and $\beta$ (see Fig. 2). In the case of specimens after 2 and $4 \mathrm{~h}$ oxygenation, a network of developing semi-elliptic cracks could be seen in the oxygenated layer near the main crack (Figs. 3, 4). Fig. $3 a$ presents the specimen surface after $2 \mathrm{~h}$ oxygenation, tested during $N_{f}=28.000$ cycles.

Fig. $3 b$ illustrates the specimen surface after $4 \mathrm{~h}$ oxygenation under the same loading and $N_{f}=19.000$ cycles. The scale residue was removed from the surface by grinding, so the metallic oxygenated base was exposed. The semi-elliptic network of the fatigue cracks occurs only in the oxygenated layer, over all its thickness, and progressively disappears as a degree of hardening decreases (see Fig. $3 c, d$ ). Fig. 3 gives the structure in deeper layers of the specimen after $2 \mathrm{~h}$ oxygenation, after removing about $60 \mu \mathrm{m}$. Semi-elliptic cracks forming the network run through the grains of Tia(O)-phase and along the boundaries of grains. In order to analyze crack growth, the chosen crack interval in Fig. $3 c$ was magnified to $\times 500$ (Fig. $3 d$ ). In Fig. $3 d$, one can see of the crack network development in deeper layers with poor content of oxygen and rich $\beta$-phase. The development stops in the $\beta$-phase grains (in the ground layer the semi-elliptic crack network is not visible).
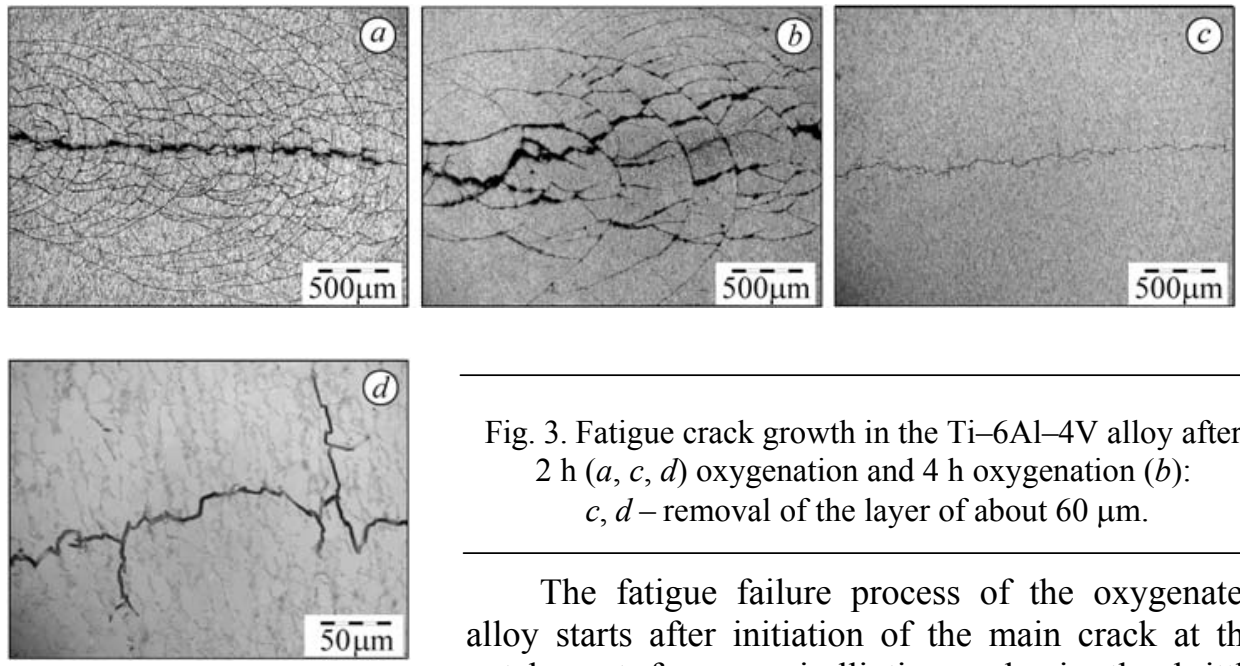

Fig. 3. Fatigue crack growth in the Ti-6Al-4V alloy after $2 \mathrm{~h}(a, c, d)$ oxygenation and $4 \mathrm{~h}$ oxygenation $(b)$ : $c, d$-removal of the layer of about $60 \mu \mathrm{m}$.

The fatigue failure process of the oxygenated alloy starts after initiation of the main crack at the notch root from semi-elliptic cracks in the brittle hardened top layer (Fig. 4). The structure after $4 \mathrm{~h}$ oxygenation is also shown. The semi-elliptic cracks precede and strongly determine propagation of the main crack, developing on the planes of the greatest normal stresses. Thus, the main crack becomes a big, zigzag-shaped, irregular crack (Fig. $4 c$ ) and it differs from the path of the main crack after $2 \mathrm{~h}$ oxygenation (Fig. $3 a$ ). Fig. $4 b$ presents the magnified crack area from Fig. $4 a$. In Fig. $4 b$ one can see the development of short cracks initiating in the network of semi-elliptic cracks blocked in the $\beta$-phase grains. Character and growth of fatigue cracks shown in Fig. 3 depend on the thermo-chemical treatment time. The network of semi-elliptic cracks for a specimen after $4 \mathrm{~h}$ oxygenation requires much more area than such network for a specimen after $2 \mathrm{~h}$ oxygenation. The main crack growth after $2 \mathrm{~h}$ oxygenation is uniform, and after $4 \mathrm{~h}$ oxygenation the crack displaces at the intervals of the semi-elliptic cracks network (Fig. 4). 

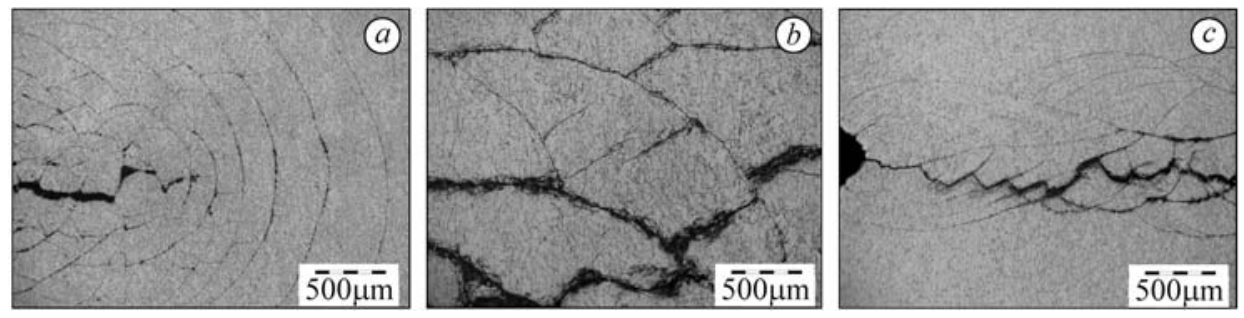

Fig. 4. Network of the fatigue cracks in the specimen after $4 \mathrm{~h}$ oxygenation: visible front of the main crack and the preceding elliptic cracks $(a, b)$ and zigzag-shaped course of the main crack determined by the network of semi-elliptic cracks $(c)$.

Characteristics of fatigue crack growth. Variation of the crack length depending on a number of loading cycles $a=f(N)$ for specimens without oxygenation, after 2 and $4 \mathrm{~h}$ oxygenation is presented in Fig. 5. Comparing fatigue life of the considered alloy before oxygenation and after $2 \mathrm{~h}$ oxygenation, we can notice its treble increase and for $4 \mathrm{~h}$ oxygenation, a double increase can be noticed. Graphs of the fatigue crack growth rate $d a / d N=f(\Delta K)$ for specimens before and after 2 and $4 \mathrm{~h}$ oxygenation are shown in Fig. 6. From analysis of the test results it appears that after 2 or $4 \mathrm{~h}$ oxygenation the fatigue crack growth rate decreases (more after $4 \mathrm{~h}$ ) in all amplitude range of $\Delta K$ as compared with the fatigue crack growth rate in the specimens without oxygenation. For example, for $\Delta K=28 \mathrm{MPa} \cdot \mathrm{m}^{1 / 2}$, we can observe decrease of the fatigue crack growth rate about three times after $2 \mathrm{~h}$ and about two times after $4 \mathrm{~h}$ oxygenation (from $6.70 \cdot 10^{-7} \mathrm{~m} /$ cycle without oxygenation to $2.73 \cdot 10^{-7} \mathrm{~m} /$ cycle after $2 \mathrm{~h}$ oxygenation and $3.50 \cdot 10^{-7} \mathrm{~m} /$ cycle after $4 \mathrm{~h}$ oxygenation).

Coefficients $C, m$ and correlation coefficients $r$ for the graphs shown in Fig. 6

\begin{tabular}{|c|c|c|c|}
\hline Graph in Fig. 6 & $C, \mathrm{~m}\left(\mathrm{MPa} \cdot \mathrm{m}^{1 / 2}\right)^{-\mathrm{m}} /$ cycle & $m$ & $r$ \\
\hline 1 & $7.656 \cdot 10^{-9}$ & 1.230 & 0.946 \\
\hline 2 & $3.669 \cdot 10^{-9}$ & 1.267 & 0.980 \\
\hline 3 & $1.089 \cdot 10^{-8}$ & 1.015 & 0.945 \\
\hline
\end{tabular}

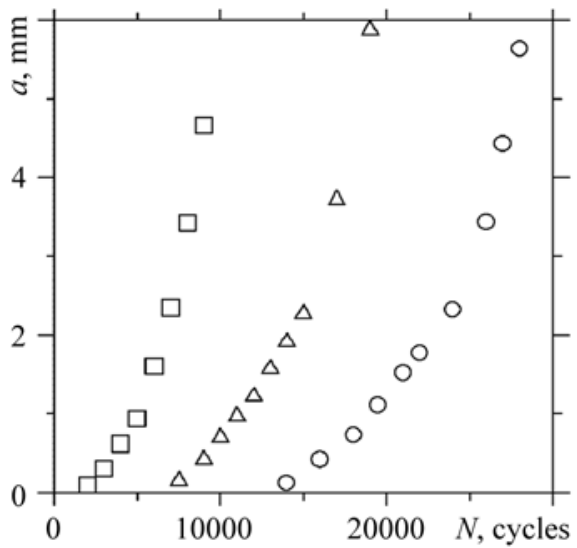

Fig. 5.

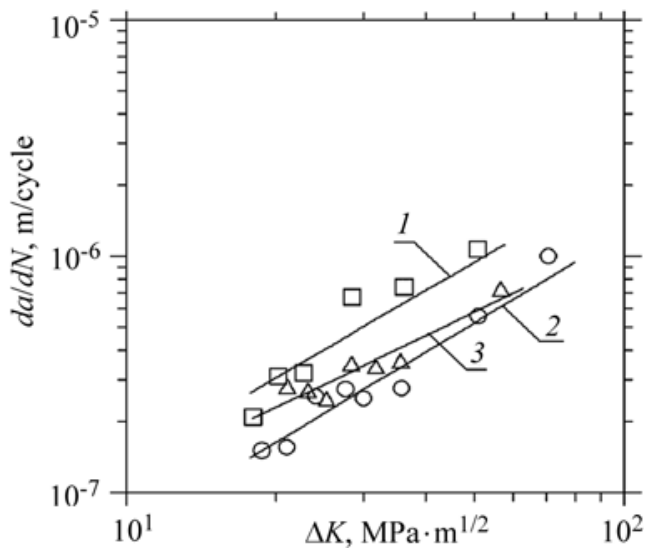

Fig. 6.

Fig. 5. Fatigue crack length, $a$, versus number of cycles, $N$ :

$\square$ - without oxygenation; $O-2$ h oxygenation; $\triangle-4$ h oxygenation.

Fig. 6. Fatigue crack growth rate $d a / d N$ versus changes of stress intensinty factor range $\Delta K$ : 1 - without oxygenation; $2-2 \mathrm{~h} ; 3-4$ h oxygenation. 
The test results (Fig. 6) were approximated with the Paris equation [8]. The coefficients $C$ and $m$ were determined with the least square method and shown in the Table. It contains also the correlation coefficients $r$ which were determined for the significance level $\alpha=0.05$. The coefficients $r$ are high (close to unity), so there is strong linear dependence between variables $d a / d N$ and $\Delta K$ described by experimental results. The relative error of test results for cyclic bending does not exceed $20 \%$ when using $\Delta K$ parameter.

\section{CONCLUSIONS}

The presented results of the fatigue crack growth in the plane specimens subjected to bending loading allow to formulate the following conclusions: the network of semielliptic cracks can be seen in the specimens after oxygenation; the network of semi-elliptic cracks occurs in the layers rich in oxygen; micro-hardness of the oxygenated layers is more than two times greater than that of the basic material; lifetime of the tested alloy without oxygenation was compared with its lifetime after oxygenation. The lifetime increased about three times after $2 \mathrm{~h}$, and about two times after $4 \mathrm{~h}$ oxygenation.

PЕЗЮМЕ. Досліджено втомний ріст тріщин у титановому сплаві Ti-6Al-4V у вихідному стані та після високотемпературного насичення киснем на плоских зразках товщиною $4 \mathrm{~mm}$ з одностороннім боковим надрізом за навантаження згином. Виконано фрактографічний аналіз особливостей втомного росту тріщини і визначено ії швидкість для різних станів металу: у вихідному та після 2 i 4 h насичення киснем. Виявлено, що хімікотермічна обробка впливає на втомний ріст тріщини, при цьому підвищується втомна довговічність.

PЕЗЮМЕ. Исследован усталостный рост трещин в титановом сплаве Ti-6Al-4V в исходном состоянии и после высокотемпературного насыщения кислородом на плоских образцах толщиной $4 \mathrm{~mm}$ с односторонним боковым надрезом при нагружении изгибом. Проведен фрактографический анализ особенностей усталостного роста тещин и определена её скорость для разных состояний металла: в исходном и после 2 и $4 \mathrm{~h}$ насыщения кислородом. Выявлено, что химико-термическая обработка влияет на усталостный рост трещин, при этом повышается усталостная долговечность.

1. Rozumek D. and Hepner M. Influence of the Ti-6Al-4V titanium alloy microstructure on the fatigue crack growth // Mater. Engn. - 2005. - 2. - P. 81-83 (in Polish).

2. Rozumek $D$. and Macha E. Fatigue crack growth in titanium and aluminum alloys under bending // Mater. Science Forum. - 2007. - 567-568. - P. 317-320.

3. Rozumek D. and Hepner M. Analysis of the fatigue crack growth in Ti-6Al-4V alloy without and after oxygenation // Mater. Engn. - 2008. - 3. - P. 154-156 (in Polish).

4. Interstitial hardening of the surface of titanium alloys by vacuum heat treatment / V. M Fedirko, A. T. Pichuhin, O. H. Luk'yanenko, and V. S. Onuferko // Materials Science. -2005. - 41, № 2. - P. 208-216.

5. Endurance of VT1-0 titanium alloy subjected to solid-solution surface hardening / A. T. Pichuhin, V. M. Fedirko, O. H. Luk’yanenko, and V. S. Onuferko // Ibid. - № 3. - P. 418-422.

6. Nalla R. K., Campbell J. P., and Ritchie R. O. Mixed-mode, high-cycle fatigue-crack growth thresholds in Ti-6Al-4V: Role of small cracks // Int. J. of Fatigue - 2002. - 23. - P. 1047-1062.

7. Fatigue and microstructure of two-phase titanium alloys // W. Ziaja, J. Sieniawski, K. Kubiak, and M. Motyka // Mater. Engn. - 2001. - 22. - P. 981-984 (in Polish).

8. Paris P. C. and Erdogan F. A critical analysis of crack propagation laws // J. Basic Eng., Trans. ASME. - 1960. - 85. - P. 528-534. 